KENOSIS : JURNAL KAJIAN TEOLOGI

ISSN 2460-6901(Print), 2656-4483 (Online)

https://e-journal.iaknambon.ac.id/index.php/KNS

DOI: 10.37196/kenosis.v7i2.377

\title{
MASKAWIN DALAM SISTEM PERKAWINAN TUKAR SUKU ISIRAWA DI KAMPUNG WARI, SARMI, PAPUA
}

\section{Lisa Marpaung}

Sekolah Tinggi Filsafat Theologi Jakarta

J1. Proklamasi No.27, RT.11/RW.2, Pegangsaan,

Kec. Menteng, Kota Jakarta Pusat, DKI Jakarta 10320

lisamarpaunglove@gmail.com

\begin{abstract}
This paper aims to explore and document the concept and meaning of dowry in the Isirawa people bride exchange system, determines its impact on women and children, and provides a reflective analysis from a feminist point of view regarding the dowry payment system. The research used the feminist ethnography qualitative method through literature studies, interviews, and observations. The results found that the dowry exchange system, when viewed from a positive side, means that women or children are considered very valuable and vital for the Isirawa community, namely to strengthen kinship between families and clumps, to continue the clan, as a tool of peace in a conflict as prevention of domestic violence. However, on the other hand, it has a negative impact that is more detrimental to women, namely limiting women's rights, violence, and unfair treatment of women and children. So, it needs to be criticized and consider changing some parts of the tradition that marginalize them by providing solutions, understandings, and new Christian values not to eliminate the existing culture but continue to enable carrying out the tradition for the welfare of the people without harming the other.
\end{abstract}

Keywords: Bride exchange, children, Isirawa, dowry, women.

\begin{abstract}
Abstrak
Tulisan ini bertujuan untuk mengeksplorasi dan mendokumentasikan konsep dan makna maskawin dalam sistem perkawinan tukar pada Suku Isirawa, melihat dampaknya bagi perempuan dan anak, serta memberikan analisis reflektif dari sudut pandang feminis mengenai hal tersebut. Penelitian ini menggunakan metode
\end{abstract}


kualitatif etnografi feminis, melalui studi kepustakaan, wawancara, dan observasi. Hasilnya ditemukan bahwa pada sistem tukar-menukar maskawin tersebut jika dilihat dari sisi positif memiliki makna perempuan atau anak dianggap sangat berharga dan penting bagi masyarakat Isirawa, yakni untuk mempererat kekerabatan antar keluarga dan rumpun, meneruskan marga, dan sebagai alat perdamaian konflik seperti untuk mencegah kekerasan dalam rumah tangga. Tetapi, di sisi lain memiliki dampak negatif yang merugikan, beberapa di antaranya membatasi hak-hak perempuan, terjadi kekerasan, dan perlakuan tidak adil terhadap perempuan dan anak. Dengan demikian, perlu dikritisi dan dipertimbangkan untuk mengubah beberapa bagian tradisi yang memarinalkan tersebut dengan bersama-sama memberi solusi, pemahaman, dan nilai Kristiani yang baru, sehingga tidak serta-merta menghilangkan total budaya yang ada. Sebaliknya, tradisi tetap dapat terlaksana untuk menyejahterakan umat tanpa merugikan salah satu pihak.

Kata kunci: Anak, Isirawa, maskawin, perkawinan tukar, perempuan.

\section{PENDAHULUAN}

Kebudayaan di Indonesia sangat beraneka ragam. Hildred Geertz juga melihat keragaman budaya masyarakat Indonesia dari keanekaragaman keyakinan agama, adaptasi ekonomi, bahasa, perbedaan bentuk masyarakat (desa kecil sampai kota), model sistem hubungan keluarga (pola matrilineal, patrilineal dan model campuran), perbedaan pada struktur politik tradisional sampai kepada kerajaan. ${ }^{1}$ Menurut Taylor, kebudayaan adalah kumpulan dari kebiasaan, kemampuan, moral, kepercayaan, pengetahuan, hukum, kesenian, adat istiadat yang diperoleh yang diperoleh seseorang dalam suatu anggota masyarakat. ${ }^{2}$

Salah satu bagian kebudayaan yang penting dalam masyarakat adalah sistem perkawinan. Sistem perkawinan bertujuan untuk meresmikan dua orang menjadi suatu ikatan yang dapat diakui sah baik secara norma adat, sosial, agama, dan hukum dengan melibatkan keluarga besar dan masyarakat setempat. Upacara pernikahan sangat beragam menurut setiap tradisi suku, budaya, kelas sosial dan agama dalam kelompok masyarakat. Kondisi lingkungan, pengetahuan, agama, pengalaman, dan keyakinan yang terdapat dalam masyarakat tertentu sangat berpengaruh terhadap mode dari sistem perkawinannya. Tata aturan pernikahan dipertahankan turuntemurun oleh para anggotanya dari leluhur mereka. ${ }^{3}$ 
Begitupun juga dengan sistem perkawinan masyarakat suku Isirawa secara khusus penulis mengambil sampel di Kampung Wari, Distrik Pantai Barat, Kabupaten Sarmi, Provinsi Papua. Suku Isirawa secara umum memiliki sistem aturan pernikahan, salah satu yang penulis soroti adalah mengenai sistem pembayaran mahar atau bagi orang Papua sering disebut sebagai maskawin. Maskawin yang dimaksud yaitu maskawin tukar-menukar. Objek yang dijadikan sebagai alat pembayaran maskawin tersebut adalah manusia (perempuan atau anak). Artinya mempelai laki-laki yang ingin melamar mempelai perempuan harus membayar maskawin dengan memberikan saudara perempuannya kepada keluarga mempelai perempuan yang kemudian akan dinikahkan kembali dengan saudara laki-laki dari mempelai perempuan. Jika dari pihak laki-laki tidak memiliki saudara perempuan maka, anak dari kedua pasangan yang akan menikah tersebut nantinya wajib diserahkan sebagai maskawin kepada pihak keluarga perempuan, maka dapat dianggap lunas. Istilahnya ada "penggantian anak" bagi pihak keluarga perempuan yang telah diambil oleh pihak keluarga laki-laki untuk dinikahi. Memang tradisi ini dalam perkembangannya terutama pada generasi yang lebih muda sudah mulai tergeser dengan arus budaya modern dan ajaran Kekristenan tetapi, tidak dapat disangkal bahwa tradisi ini masih dilaksanakan sampai sekarang dan menjadi budaya yang hidup melekat bagi masyarakat Isirawa.

Bagi masyarakat Isirawa adat maskawin tukar memiliki nilai positif untuk mempersatukan kedua keluarga, mempererat kekerabatan dalam masyarakat, meneruskan marga. Denda adat (memberikan manusia) juga diberlakukan ketika terjadi konflik misalnya ketika perang, atau kekerasan dalam rumah tangga, maka jalur perdamaiannya adalah memberikan anak kepada pihak yang dirugikan. Sehingga, diharapkan dapat meredam konflik.

Namun, terdapat pula persoalan hak asasi manusia, ketidaksetaraan gender, persoalan anak, kekerasan, kumpul kebo (pernikahan tidak sah) dan lain sebagainya. Terkadang aturan-aturan tersebut memberi dampak terutama bagi perempuan dan anak. Tulisan ini bertujuan membahas pertama, konsep dan makna maskawin dalam sistem perkawinan tukar etnik Isirawa. Kedua, dampak positif dan negatif bagi perempuan dan anak. Ketiga, memberikan analisis reflektif penulis dengan menggunakan sudut pandang feminis mengenai sistem pembayaran maskawin tersebut. 


\section{METODE PENELITIAN}

Artikel ini menggunakan metode penelitian kualitatif deskriptif melalui pendekatan etnografi feminis. Etnografi feminis didasarkan pada peneliti yang secara aktif berpartisipasi dalam produksi pengetahuan sosial melalui partisipasi langsung dalam memahami realitas. Kekhususan metode ini adalah kekhasan dari perspektif perempuan, yaitu perlu secara terus menerus dan reflektif memperhatikan pentingnya gender sebagai ciri dasar dari semua kehidupan sosial dan memahami realitas sosial perempuan. ${ }^{4}$ Objek kajian penelitian ini adalah hasil observasi dan wawancara beberapa masyarakat Isirawa dengan sampel penelitian di Kampung Wari, Distrik Pantai Barat, Kabupaten Sarmi, Provinsi Papua yaitu mewawancarai kepala adat kampung Wari, tokoh agama, dan beberapa warga kampung yang kemudian dikaji dengan studi kepustakaan dari berbagai literatur seperti jurnal, skripsi, buku-buku kebudayaan Papua dan literatur feminis teologis.

\section{HASIL DAN PEMBAHASAN}

\section{Pengertian Maskawin dalam Pernikahan}

Menurut Kamus Istilah Antropologi, pernikahan atau perkawinan (marriage) adalah norma hubungan antara seorang perempuan dan laki-laki atau lebih yang disahkan menurut prosedur agama, adat-istiadat, atau hukum dalam suatu kelompok masyarakat dan mempunyai konsekuensi sosial, ekonomis, keagamaan, dan hukum. ${ }^{5}$

J.L.Ch Abineno menjelaskan pernikahan dalam sudut padang Kristiani bahwa pernikahan merupakan lembaga ataupun wujud persekutuan hidup bersama yang diatur serta disahkan oleh pemerintah lewat hukum serta oleh gereja lewat pemberkatan nikah kudus. ${ }^{6}$ Dalam pernikahan atau perkawinan setiap suku bangsa memiliki konsep dan makna maskawin yang beragam. Definisi maskawin (bride prico) dalam kamus Antropologi yakni: "barang-barang berharga yang diberikan kepada orang tua mempelai perempuan oleh mempelai laki- laki atau kerabatnya (ataupun sebaliknya)". ${ }^{7}$

Dalam tulisan ini yang dimaksud dengan maskawin adalah pembayaran dengan melakukan pertukaran gadis atau secara khusus dalam budaya Isirawa dapat juga memberikan anak kepada pihak keluarga perempuan sebagai alternatif lainnya. Adat perkawinan tukar gadis (bride exchange) menurut Koentjaraningrat adalah adat 
yang: "seorang laki-laki yang melamar seorang perempuan harus mempersiapkan saudara perempuannya dari kerabatnya sendiri untuk dinikahkan dengan seorang lakilaki dari keluarga calon istrinya" ${ }^{\prime 8}$ atau dalam kasus ini juga memberikan anak mereka sebagai maskawin.

\section{Gambaran Etnografi Suku Isirawa (di Kampung Wari)}

Suku Isirawa merupakan salah satu suku besar yang ada di Kabupaten Sarmi, Provinsi Papua. Kabupaten Sarmi meliputi wilayah seluas $35.587 \mathrm{Km}^{2}$. Ibu kota kabupaten adalah Kota Sarmi yang dibagi menjadi 8 kecamatan. Wilayahnya sebelah utara berbatasan dengan Samudera Pasifik, bagian selatan Kabupaten Tolikara, sebelah barat Puncak Jaya dan Waropen, dan di sebelah timur berbatasan dengan Kabupaten Jayapura. ${ }^{9}$ Daerah Sarmi terletak diantara beberapa sungai dan memiliki daerah perairan sungai yang cukup besar seperti sungai Apawer, Waim, Ferkame, Woske dan masih banyak lagi sungai kecil yang dimilikinya. Di bagian hilir, adalah dataran berawa makin ke arah selatan berubah menjadi bukit-bukit dan pegunungan. ${ }^{10}$

Nama Sarmi sendiri diberikan oleh antropolog Belanda yang bernama Van Kouhen Houven. Nama itu adalah sebuah singkatan dari nama kelima suku-suku besar di Sarmi yaitu: Sobey, Armati, Rumbuai, Manirem, dan Isirawa. Mengenai jumlah suku di Sarmi, sebenarnya, masih terdapat beberapa suku lainnya, karena terdapat 87 bahasa yang ada di Sarmi, namun kelima suku terebut yang paling banyak disebutkan. $^{11}$

Dalam artikel ini penulis mengambil sampel pada Suku Isirawa di Kampung Wari satu dari beberapa kampung yang bersuku Isirawa. Menurut data Tahun 2018 Jumlah kepala keluarga kampung Wari adalah 27 KK. Dengan laki-laki sebanyak 64 orang dan perempuan 83 orang dengan total jumlah penduduk sebanyak 147 orang. ${ }^{12}$

Berdasarkan letak geografi, Kampung Wari berada di wilayah pemerintahan Kabupaten Sarmi, Distrik Pantai Barat, Provinsi Papua. Kampung Wari, salah satu tempat yang masyarakatnya bersuku Isirawa dengan ketinggian 2,00 meter diatas permukaan laut. Kampung ini berada di pesisir pantai Barat Sarmi. Bagian utara berbatasan Lautan Pasifik, bagian selatan berbatasan dengan Gunung Baim (Tetnoania), bagian barat berbatasan dengan Kampung Aruswar, dan bagian timur berbatasan dengan Kampung Martewar. 


\section{Bahasa}

Menurut Koentjaraningrat, rumpun-rumpun kecil seringkali memiliki bahasa yang khusus. Perbedaannya mulai dari logat dan bahasa yang seringkali tidak bisa di pahami oleh keseluruhan hanya antar rumpun kecil atau bahkan hanya dimengerti oleh beberapa keluarga saja karena proses diaspora dan isolasi yang cukup lama. Koentjaraningrat membagi beberapa kelompok bahasa di Sarmi yaitu: kelompok bahasa Airoran, Samorkena, Kwerba, Sabori, dan Sobei. ${ }^{13}$ Menurut warga kampung wari, Bahasa yang digunakan masyarakat Kampung Wari adalah bahasa "Isirawa" yang berarti: Orang yang tinggal di rawa, lebih tepatnya bahasa "Sawere/Saveri/saberi.",14

\section{Sistem Mata Pencaharian}

Sistem mata pencaharian dari masyarakat Isirawa secara umum termasuk kampung Wari adalah bercocok tanam sayur mayur dalam skala kecil untuk kebutuhan sendiri dan sebagian diperdagangkan di pasar-pasar. Beberapa kegiatan utama lainnya adalah mengumpulkan sagu sebagai bahan makanan pokok, menangkap ikan dan berburu.

Selain itu, mata pencaharian pokok yang paling digemari adalah mengolah buah kelapa. Kegiatan itu lebih banyak dilakukan oleh kaum perempuan. Kelapa diolah menjadi minyak (minyak putih dan minyak merah-masak). Untuk minyak putih dijual ke pengelola produk minyak kelapa Phico yaitu Lembaga Pengembangan Ekonomi Lokal Daerah Kabupaten Sarmi untuk diproduksi. Minyak kelapa ini diproduksi menjadi sabun mandi, coconut cooking oil (minyak goreng), dan obat herbal Virgin Coconut Oil. Sedangkan untuk minyak merah diolah kembali dan dimasak untuk keperluan sehari-hari. Selain itu, ada juga beberapa warga masyarakat yang sudah bekerja dalam pemerintahan baik itu sebagai aparat kampung, honorer dan pegawai negeri sipil.

\section{Sistem Kekerabatan}

Menurut Koentjaraningrat dan Bachtiar, secara umum, kekerabatan adalah satu-satunya asas yang bersifat menghubungkan semua aktivitas yang hidup bersama di masyarakat Sarmi agar lebih terikat. Dalam masyarakat Sarmi (termasuk Suku 
Isirawa), pada umumnya memiliki dua macam kekerabatan, yaitu: pertama, hubungan kandung dapat lebih yang dibagi menurut darah dan hubungan perkawinan. Kedua, hubungan kekerabatan fiktif berdasarkan adat atau kebiasaan. ${ }^{15}$

Keturunan dilihat pada laki-laki (patrilineal). Selain itu, orang juga memiliki beberapa kerabat yang diakibatkan dari perkawinan, seperti semua kerabat istri, menantu, atau semua istri dan suami dari kerabat. Sedangkan hubungan fiktif adalah hubungan yang terjadi karena nenek moyang kerabat diadopsi oleh nenek moyangnya. Hubungan fiktif juga dapat terjadi, melalui pemberitahuan oleh orang tua mereka turun-temurun padahal tidak memiliki hubungan darah. Sehingga terkadang mereka tidak tahu bahwa mereka bukan saudara sedarah. ${ }^{16}$

Ada tiga macam kelompok kerabat yaitu: keluarga inti, persekutuan keluarga, dan rumpun. Pertama, keluarga inti yaitu terdiri dari seorang ayah, ibu dan anak-anak, sering di tambah dengan anak angkat. Biasanya satu keluarga inti bertempat tinggal dalam satu rumah, namun terdapat pula sebagian keluarga yang hidup dengan beberapa keluarga dalam satu rumah, dan kepala rumah tangga merupakan bapak yang tertua. Keluarga inti ini ialah satu kesatuan kerja yang mencari nafkah bersama. Selain itu, keluarga tersebut memiliki peranan yang sangat penting sebagai pusat pengasuhan serta pembelajaran anak- anak. Kedua, persekutuan-persekutuan keluarga ialah kelompok saudara yang luas yang terikat secara patrilineal. Jalinan Patrilinear itu mula-mula terjalin oleh sebab pernikahan yang patrilokal. Maksudnya, setelah menikah, laki-laki tidak meninggalkan wilayah asal mereka. Namun, mereka senantiasa membawa istrinya kembali menetap di kampungnya. Ketiga, ialah rumpun yakni berdasarkan pada kesatuan daerah, kesatuan bahasa, jalinan sesuatu nama yang terikat dengan ikatan kekerabatan yang lebih luas dengan rumpun yang lain. Ikatan kekerabatan antar rumpun ini dapat terjalin oleh sebab pernikahan antar rumpun. ${ }^{17}$

\section{Konsep Maskawin Etnik Isirawa}

\section{Adat Maskawin}

Dalam adat istiadat suku Isirawa (termasuk kampung Wari), menggunakan sistem perkawinan tukar menukar. Ketika laki-laki dan perempuan telah bersepakat untuk menikah, maka pihak keluarga laki-laki harus memberikan saudara perempuannya kepada pihak keluarga perempuan dan dinikahkan dengan keluarga 
dari pihak perempuan sebagai maskawinnya (istilahnya ada "penggantian anak" bagi pihak keluarga perempuan yang telah diambil).

Hal ini juga pernah dijelaskan oleh Koentjaraningrat dan Bachtiar, bahwa:

Orang yang kawin dengan seorang gadis, harus seolah-olah memberi pengganti kerugian kepada kaum kerabat si gadis. Cara penggantian ini pada orang Sarmi berbentuk suatu yang dalam ilmu antropologi disebut bride-exchange, artinya seorang yang melamar seorang perempuan harus menyediakan adik perempuan atau kerabat perempuan lainnya untuk diberikan kepada kaum kerabat si perempuan supaya dikawinkan dengan seorang pemuda dari sana. ${ }^{18}$

Di lain sisi, jika pihak laki-laki tidak memberikan saudaranya sebagai maskawin atau tidak memiliki saudara perempuan maka, ketika kedua pasangan yang menikah ini suatu saat memiliki anak, mereka harus menyerahkannya sebagai maskawin kepada pihak keluarga perempuan, sehingga dapat dianggap lunas. ${ }^{19}$ Itu dikatakan sebagai pengganti dan penerus marga.

Dari keterangan di atas ketika semua ketentuan maskawin itu telah diberikan maka dapat dilangsungkan pernikahan. Seperti yang dijelaskan sebelumnya, bahwa biasanya ketika telah menikah dan diakui secara adat maka pengantin laki-laki akan membawa pengantin perempuan ke desa laki-laki, tetapi pengecualian untuk yang belum memberikan maskawin tersebut. Mereka harus tetap tinggal di rumah keluarga perempuan yang diistilahkan warga setempat dengan "kawin masuk." Jika kekerasan kepada perempuan selama belum memberikan maskawin, maka akan di berikan sangsi adat (denda) yaitu teguran atau memberikan anak sebagai ganti rugi kepada pihak keluarga perempuan. Pihak yang diberikan anak itu harus merawat anak itu dengan sebaik-baiknya. ${ }^{20}$

Mengenai asal usul sejarah maskawin tukar ini, tidak diketahui secara pasti namun, menurut tulisan Kasim menjelaskan bahwa: Sejarah maskawin tukar menukar (di kampung Karfasia) ini disinyalir dimulai ketika nenek moyang dari suku Isirawa bertempat pertama kali di daerah Aurimi, masyarakat tersebut pergi ke daerah Nisro dan kemudian menyeberang ke daerah pesisir yang sekarang di sebut Pantai Barat, tujuan dari kedatangan mereka adalah membawa air asin, bia acaufa, dan juga 
ikan besar. Mereka datang berkelompok kemudian bertemu dengan kelompok lain, marga pertama yang datang ke daerah pesisir adalah marga Aweta dan yang kedua adalah marga Sunuk. Dari pertemuan inilah kelompok dari Aurimi bertemu dengan kelompok yang berada di pesisir, pertemuan antara seorang pria dari Aurimi dan seorang wanita dari pesisir, di situlah maskawin tukar-menukar mulai berkembang, hal ini terbawa juga dari kebiasaan masyarakat dalam hal membalas budi atau lebih di kenal dengan barter, kebiasaan ini terbawa sampai ke dalam tatanan adat yang lebih di khususkan yaitu pembayaran maskawin tukar-menukar manusia. ${ }^{21}$ Disinyalir, dari beberapa percakapan dengan beberapa narasumber dapat disimpulkan walaupun belum diketahui secara pasti kebenarannya bahwa, pada zaman dahulu, masyarakat masih menggunakan harta berupa benda-benda berharga sebagai alat tukar maskawin, tetapi, seiring berjalannya waktu dengan kondisi dan keterbatasan ekonomi masyarakat maka, digunakan manusia sebagai alat pertukarannya.

\section{Upacara Pernikahan}

Zaman dahulu, ketika seorang laki-laki akan menikahi seorang perempuan dari kampung lain, maka kedua pihak keluarga mempersiapkan diri (pesta dan makanan) di masing-masing kampung. Makanan itu akan dipertukarkan: pihak laki-laki memakan makanan yang dimasak keluarga perempuan begitu pun sebaliknya, dan akan bertemu sesuai waktu yang ditentukan. Zaman dulu orang-orang menggunakan tali (diikat-ikat) yang dipotong-potong untuk menentukan hari pernikahan atau pertemuan itu. Tali satu dipegang oleh pihak keluarga laki-laki, tali lainnya juga dipegang oleh pihak keluarga perempuan. Ketika tali yang dipotong-potong itu tersisa 2 mereka sudah mulai mendekati hari pernikahan. ${ }^{22}$

Saat hari pernikahan tiba, pihak keluarga laki-laki mendatangi rumah keluarga perempuan (atau secara umum biasanya diselenggarakan di rumah pihak laki-laki) sambil membawa saudaranya perempuan, untuk diberikan sebagai maskawin disertai dengan membawa hasil alam dan makanan yang sudah disiapkan. Jadi, pada saat membawa saudara perempuan dari pihak laki-laki sebagai maskawin, mereka tidak mengetahui kepada siapa perempuan tersebut akan dinikahkan. ${ }^{23}$

Saat mereka memasuki halaman rumah, mereka melempar papeda panas pada tubuh pihak pengantin perempuan, mencoba apakah pengantin perempuan adalah 
perempuan baik-baik atau apakah pernikahan mereka akan terselenggara dengan baik atau tidak. Jika papeda yang dilempar pada tubuh perempuan tetap melekat sampai menjadi dingin maka, masyarakat setempat percaya bahwa itu adalah tanda pengantin perempuan adalah perempuan yang baik, setia, dan pernikahan mereka akan berjalan dengan baik. Tetapi sebaliknya, jika papeda panas itu jatuh dari badan perempuan maka kemungkinan itu adalah tanda bahwa perempuan tersebut adalah perempuan yang tidak baik: cerewet, tidak setia, dan lain sebagainya. ${ }^{24}$

Setelah itu ada orang yang melakukan tarian "cakalele" (tari adat) yang terdapat pembicaraan di dalamnya, misalnya: “Kau ini perempuan bagus ka?” atau kepada mempelai laki-laki: "Kalau kau bikin macam-macam ada jubi ini”. Setelah itu, terjadi pertukaran dari pihak perempuan yaitu pengantin perempuan diserahkan kepada pengantin laki-laki. Sedangkan, saudara perempuan dari pihak laki-laki diserahkan sebagai maskawin kepada pihak keluarga perempuan dengan prosesi bergandengan tangan maka, di situlah telah terjadi pernikahan. Setelah itu barulah acara makan bersama dilangsungkan. ${ }^{25}$

Lebih lanjut Koentjaraningrat menjelaskan, pada umumnya masyarakat Sarmi (tidak hanya di kampung Wari) biasanya menggelar pernikahan di desa mempelai pria. Kerabat pengganti pria adalah penyelenggara dan tuan rumah dalam pertemuan itu. Acara utama dari pernikahan adalah ritual untuk kedua mempelai memakan bubur sagu yang dimasak sendiri oleh mempelai perempuan. Hal itu melambangkan status perempuan sebagai pengatur ekonomi keluarga. Dengan dilangsungkannya upacara itu maka, perkawinan telah diresmikan. Upacara penting lainnya adalah keluarga laki-laki menyerahkan perempuan kepada keluarga mempelai perempuan, upacara ini disertai dengan tukar menukar cendera mata dan kemudian pestanya dimeriahkan dengan musik tradisional. Setelah itu, perempuan akan tinggal di wilayah kerabat laki-laki (patrilokal). Secara umum, pernikahan di Sarmi adalah monogami. Pernikahan poligami jarang terjadi. Sekalipun terjadi, itu hanya terjadi pada orang-orang yang memiliki pengaruh, atau karena adat levirat. Adat levirat mengharuskan seseorang menikah dan mengurus janda dan anak-anak dari saudara laki-lakinya yang baru saja meninggal. ${ }^{26}$

Kalau suami meninggal, menurut adat dapat dinikahkan kembali dengan saudaranya dari pihak laki-laki. Pada zaman sekarang, tergantung dari kemauan 
perempuan walaupun tentu ada unsur tekanan. ${ }^{27}$ Jika perempuan meninggal dan sudah melahirkan anak berarti sudah lunas (sudah diganti). Tetapi, jika perempuan sudah meninggal dan belum mempunyai anak maka, dari pihak laki-laki adakalanya menuntut untuk menikahi saudara dari istri yang meninggal tersebut. ${ }^{28}$

Adat istiadat maskawin tersebut masih tetap ada sampai saat ini. Walaupun dalam beberapa kasus karena pengaruh Kekristenan dan kehidupan modern saat ini, adat tersebut sedikit mengalami kelonggaran terutama pada kalangan generasi yang lebih muda. Tetapi, pada dasarnya adat ini masih tetap kuat dipertahankan.

\section{Makna dan Dampak Maskawin Tukar Etnik Isirawa}

Makna positif dari maskawin dalam pernikahan tukar-menukar adalah perempuan dan anak dianggap sangat penting dan berharga. Selain itu, maskawin perempuan atau anak diberikan untuk mempererat kekerabatan antar keluarga dan rumpun. Perempuan atau anak yang diberikan sebagai maskawin dan dinikahkan kembali ketika menjanda bertujuan untuk menjaga dan meneruskan marga. Selain itu, pemberian perempuan atau anak berfungsi sebagai alat perdamaian atau alat ganti rugi dalam menyelesaikan konflik. Sehingga, diharapkan perceraian dan kekerasan dalam rumah tangga dapat dihindari atau diminimalisir akibat sanksi adat yang diberlakukan.

Dampak negatifnya adalah perempuan seolah-olah seperti komoditi yang dapat dipertukarkan, diberikan, atau dipakai. Dalam beberapa kasus perempuan tidak memiliki hak kebebasan untuk memilih pasangannya atau memilih untuk tidak menikah kembali. Terkadang perempuan merasa terpaksa atau tertekan (jika pria tersebut tidak disukainya) karena telah terikat oleh aturan adat yang harus dipatuhi. Beberapa hanya mengikuti saja aturan yang sudah ditetapkan dari nenek moyang. Di lain sisi, karena belum dapat membayar maskawin, tidak jarang dapat ditemukan perempuan dan laki-laki yang akhirnya hidup dalam pernikahan tidak sah, tentunya itu sangat bertentangan dengan ajaran Kristiani. Dalam kasus tertentu, penulis menemukan kehidupan pernikahan yang sangat tidak harmonis yang merupakan hasil dari sistem mas kawin tersebut.

Di lain hal, jika karena keberatan-keberatan tertentu atau karena tidak memiliki saudara perempuan maka, dapat dilakukan pertukaran atau pemberian anak kandung dari kedua pasangan yang menikah tersebut, kepada pihak keluarga 
perempuan. Dampaknya, anak harus berpisah dari orang tua kandungnya sejak kecil. Orang tua kandung tentu mengalami perasaan tidak nyaman (sedih) karena harus memberikan anaknya. ${ }^{29}$ Sekali lagi, dampak bagi perasaan atau mental seorang ibu yang kehilangan anaknya tentu dapat terjadi apalagi dalam beberapa kasus tertentu, kedepannya anak tersebut akan lebih canggung kepada orang tua kandungnya (bahkan ada yang tidak saling mengenal) walaupun dalam beberapa kasus relasi orang tua kandung dan anak juga tetap ada.

Berikut beberapa contoh kasus mengenai adat ini. Di zaman dahulu, jika suami meninggal dunia maka terjadi perebutan atau bahkan perkelahian untuk menikahi istri yang ditinggalkan. Dahulu, pernah ada yang melarikan diri ke hutan sambil menggendong anaknya karena, tidak ingin dinikahi kembali. Tetapi untuk masa ini, sudah tidak lagi terlalu ketat tradisi tersebut dilakukan. Kecuali untuk adat maskawin tukar, masih dilakukan sampai saat ini. ${ }^{30}$

Kasus berikut yang terjadi beberapa tahun silam, karena konflik kekerasan dalam rumah tangga membuat seorang perempuan menjadi korban. Sehingga, dengan terpaksa perempuan lainnya harus menikah diberikan dan dinikahkan. Menurut narasumber, ada seorang Ibu X mempunyai saudara laki-laki yang memukul istrinya sampai meninggal. Sehingga, pihak keluarga yang meninggal tersebut menuntut. Maka, terpaksa harus diganti dengan Ibu X dan dinikahkan dengan Bapak Y dari pihak keluarga tersebut. Sampai sekarang Ibu X walaupun sudah menikah dengan Bapak Y tetapi tetap tidak cocok, karena Ibu Y merasa terpaksa akibat adat yang mau tidak mau harus dilakukan. ${ }^{31}$

Contoh kasus lainnya pada satu kampung tetangga, ada seorang Bapak A telah menikah dengan seorang ibu B. Jadi, saat menikah, pihak keluarga perempuan meminta ganti (maskawin) yaitu saudara perempuan $\mathrm{C}$ dari pihak laki-laki A untuk diberikan ke pihak keluarga perempuan B dan menikah dengan seorang lelaki D dari keluarga pihak perempuan. Jadi, Bapak A menikah dengan Ibu B, dan Ibu C (sebagai maskawin) menikah dengan Bapak D. Dalam kehidupan pernikahannya, Ibu C yang sebagai maskawin itu pun sangat tidak harmonis dengan suaminya Bapak D.

Kemudian, suatu waktu, ketika Bapak A meninggal, terjadilah konflik. Karena, ibu B ingin pulang kepada sanak saudaranya di kampung Wari. Tetapi, pihak keluarga dari laki-laki Bapak A tidak setuju karena, sudah membayar maskawin yaitu Ibu C ke 
kampung Wari. Sehingga, pihak keluarga laki-laki dari Bapak A yang meninggal, menuntut agar ibu B (janda) ini harus menikah kembali dengan salah satu keluarganya dari pihak Bapak A. Tetapi, Ibu janda B ini tidak mau, maka konflik pun terjadi. ${ }^{32}$

\section{Sebuah Refleksi Kritis Teologi Feminis}

Dari penggambaran budaya maskawin suku Isirawa di atas, dapat terlihat bahwa budaya di Indonesia secara khusus di Papua sangat beraneka ragam. Budaya maskawin tukar-menukar ini menarik dan memiliki keunikan tersendiri. Oleh sebab itu, penulis menghormati kesakralan dari setiap budaya suku Isirawa sebagai identitas mereka yang fundamental.

Namun, dalam budaya yang memiliki maksud positif tersebut ternyata jika dilihat dalam sudut pandang feminis, adat maskawin tukar-menukar tersebut memunculkan persoalan baru yang tidak dapat dianggap sepele yakni pertama, persoalan diskriminasi dan ketidakadilan gender terhadap perempuan. Posisi perempuan dijadikan objek dari sebuah sistem, "seperti” sebuah properti atau alat dalam konstruksi budaya untuk diberikan atau dipertukarkan sebagai maskawin atau denda. Tentunya beberapa perempuan menjadi korban dalam sistem tersebut. Bahkan, mereka juga mengalami kekerasan, berupa kekerasan dalam rumah tangga atau tekanan untuk menikah karena diberikan sebagai maskawin. Perempuan tidak memiliki kebebasan untuk memilih pasangannya atau memilih untuk tidak menikah kembali. Sehingga, perempuan tidak memiliki kontrol atas tubuhnya sendiri. Pada beberapa kasus dalam hemat penulis, beberapa pasangan perempuan dan laki-laki akhirnya hidup dalam perkawinan yang tidak sah (kumpul kebo) karena belum bisa membayar maskawin atau memilih kawin lari dan lain sebagainya.

Menurut pengamatan penulis, beberapa kehidupan pernikahan terutama yang menjalani adat sebagai maskawin sering tidak terlihat harmonis. Dalam kasus-kasus tertentu, baik perempuan ataupun laki-laki hidup bermusuh-musuhan atau saling mengambil jarak satu sama lain, perempuan secara khusus mengeluhkan keadaannya, dan sering bertengkar dalam rumah tangga. Selain karena, beberapa faktor kemabukan, kekerasan, ekonomi, perselingkuhan yang saling berkaitan. Hal itu dapat terjadi juga karena, unsur keterpaksaan atau ketidakcocokan akibat proses perkenalan dalam masa pra-pernikahan yang tidak terjadi atau terlewatkan. Padahal, secara umum 
itu merupakan salah satu unsur terpenting ketika kedua pasangan memutuskan untuk hidup dalam sebuah kehidupan pernikahan.

Persoalan kedua adalah anak harus berpisah dari orang tua kandungnya sejak dari kecil. Mereka tidak memiliki kesempatan untuk menentukan atau hidup bersama keluarga kandungnya. Walaupun, menurut pengakuan, beberapa anak menerima perlakuan yang baik dari orang tua piara mereka, seperti halnya anak sendiri. Tentu dalam tulisan ini, kajian feminis tidak hanya berbicara sebatas soal perempuan tetapi segala ranah dalam sudut pandang perempuan terhadap bentuk ketidakadilan gender yang membelenggu serta dalam memperjuangkan kesetaraan dan HAM bagi perempuan ataupun laki-laki dan secara luas seluruh makhluk termasuk anak-anak.

Mansour Fakih menjelaskan bahwa perbedaan gender bukanlah masalah sepanjang tidak memunculkan ketidakadilan gender. Tetapi, pada realitasnya perbandingan gender sudah melahirkan bermacam-macam ketidakadilan baik bagi perempuan ataupun laki-laki. Ketidakadilan gender ini menyebabkan lahirnya sifat dan stereotipe yang memarjinalkan kalangan perempuan. Jadi, yang diperjuangkan sesungguhnya bukan tentang melawan laki-laki melainkan perjuangan melawan perkara sistem serta struktur ketidakadilan dalam masyarakat publik yang tercermin dalam budaya patriakal. ${ }^{33}$ Gender sebagai sebuah pengetahuan yang dapat membuka kesempitan berpikir bahwa nasib buruk perempuan bukan hal kodrati melainkan semacam konstruksi sosial yang disahkan menjadi kodrat budaya, yang sebenarnya mampu juga memberikan solusi atas permasalahannya. Feminisme dapat ikut bersuara, karena ia dapat dikatakan sebagai spiritualitas melawan penindasan. Oleh karena itu, feminisme dapat memberikan harapan bagi perempuan (tetapi juga semua pihak yang tertindas) untuk membebaskan diri dari konstruksi nasib buruk yang menimpa mereka dengan menjalankan prinsip "bertahan tanpa penindasan" dan mengangkat sisi spiritualitas feminis sebagai sumber kekuatan rohaniah dan pemulihan untuk dapat kembali berkontribusi bagi sesuatu yang menjadi citacitanya. ${ }^{34}$ Sehingga, pembahasan dari kacamata feminis adalah sesuatu yang logis dan relevan untuk membebaskan yang tertindas, dalam hal ini perempuan dan anak dari segala macam bentuk penindasan yang diakibatkan oleh konstruksi budaya buatan manusia sendiri yang cenderung lebih memihak pada sistem patriakal. 
Budaya masyarakat Isirawa secara umum adalah partriarki yaitu, semua diukur berdasarkan peran laki-laki. Hal itu seperti yang diamati oleh Eka Kristining Rahayu bahwa, dalam kebanyakan budaya patriarkat di Indonesia, apalagi di beberapa daerah yang masih kental dengan budayanya, peran atau derajat perempuan masih ada di bawah laki-laki. Budaya patriarkat tersebut membuat perempuan terbatas dalam mengambil keputusan baik dalam keluarga ataupun dalam lingkungan masyarakat. Hal inilah yang menghasilkan persoalan ketimpangan gender antara perempuan dan laki-laki. ${ }^{35}$

Beberapa tradisi masih sangat kental dan dipegang kuat oleh masyarakat Isirawa seperti gotong-royong, sistem kekerabatan yang kuat, pernikahan, keyakinan dan nilai-nilai kultur dalam hubungannya dengan kehidupan. Karena budaya yang masih begitu sakral dan asri maka, memerlukan proses yang panjang untuk merekonstruksi nilai yang memarjinalkan tersebut dengan nilai-nilai yang baru, karena telah berakar kuat dalam konstruksi budaya secara turun-temurun. Menurut Schafer, penindasan yang dibenarkan di Asia adalah atas nama budaya tradisional dan agama (kepercayaan). Secara khusus di Indonesia perjuangan dan pergerakan keadilan perempuan lebih terhambat dan sempit dalam kehidupan budaya dan agama karena telah berakar dan dikonstruksikan dibandingkan dengan kehidupan ekonomi dan politik. ${ }^{36}$ Sehingga, perjuangan pembebasan dari ketertindasan itu bukan perkara yang mudah. Hal itu memerlukan perhatian ekstra. Padahal, adat maskawin tukar tersebut tanpa disadari sangat memihak dan paling banyak merugikan pihak perempuan dan anak.

Berdasarkan hasil penelitian, baik laki-laki atau beberapa perempuan telah terbiasa dengan adat istiadat maskawin dalam pernikahan tukar-menukar ini, sehingga kaum perempuan dan anak yang adalah objek tersebut tidak menyadari situasi marjinal tersebut, hanya bersikap biasa dan menerima kebudayaan yang ada. Realitas itu di jelaskan juga oleh Ruth Schafer seorang teolog feminis:

Harus disadari bahwa salah satu dampak dari masyarakat yang patriakal adalah bahwa perempuan menyesuaikan diri dengan keadaan yang demikian. Entah sadar atau tidak perempuan sering menyetujui kekuasaan laki-laki, mungkin paling sering dengan tetap diam dan pasif saja padahal menyadari adanya ketidakadilan. Para perempuan sendiri dapat mendukung 
anggapan umum tentang "kondrat" perempuan ... ada perempuan yang secara ikhlas mengizinkan dan menyetujui dominasi laki-laki sebagai sesuatu yang lazim... itulah kesimpulan logis dari struktur pembagian kuasa dalam masyarakat yang patriakal. ${ }^{37}$

Kemudian, kita pun perlu melihat mengapa perempuan dan anak dijadikan sebagai maskawin. Menurut hemat penulis, karena sistem patriakal yang telah mendarah daging dalam budaya. Di mana, budaya maskawin tukar-menukar perempuan atau anak kemungkinan tercetus dari budaya barter sejak dahulu dalam masyarakat Isirawa. Kehidupan masyarakat Isirawa di beberapa kampung sekitarnya sangat terbatas. Masyarakat hidup dengan berkebun, berburu, menangkap ikan, memiliki tingkat buta huruf yang tinggi, sarana kesehatan yang terbatas, sehingga dalam perkembangan sejarahnya sejak dahulu, kemungkinan maskawin yang dahulunya adalah benda-benda berharga sebagai alat tukar atau seserahan telah berganti menjadi pertukaran atau seserahan manusia (perempuan atau anak) sebagai sesuatu yang sangat berharga bagi masyarakat Isirawa. Sehingga, faktor ekonomi juga berperan dalam menentukan kebudayaan yang ada.

Oleh karena itu, perlulah kita memberi perhatian kembali akan persoalannya dan mengkritisi beberapa budaya yang lebih cenderung memarjinalkan kaum perempuan atau anak. Karena, semua insan manusia memiliki hak yang sama dan setara. Ada satu keyakinan fundamental dalam sudut pandang feminis bahwa "perempuan adalah manusia sepenuhnya dan harus diperlakukan demikian." ${ }^{38}$ Maka, kita perlu berpihak kepada orang-orang yang mengalami ketidakadilan dalam struktur kultural.

Alkitab juga secara tidak langsung berbicara demikian bahwa, perempuan adalah karya Allah yang sangat berharga sama halnya dengan laki-laki. Hal itu dapat dilihat dalam kitab Kejadian 2:18 ketika Allah menciptakan dan memberikan perempuan posisi yang sepadan dengan kaum laki-laki. ${ }^{39}$ Alkitab, jika dilihat dari sudut pandang yang berbeda dapat juga dibaca dari perspektif feminis yang benar. Karena perempuan memiliki perspektif yang berbeda dari perspektif pelaku kekerasan saat melihat teks-teks Alkitab. Pengalaman perempuan tersebut bernilai teologis bahwa Yesus berpihak kepada kaum tertindas dan minoritas. Yesus juga merasakan 
penderitaan umat-Nya, maka Yesus dilihat sebagai pembela pihak tertindas, minoritas dan yang menderita ${ }^{40}$ begitupun dengan penderitaan dan ketidakadilan bagi perempuan dan anak-anak.

Dalam panggilan kehidupan pernikahan Kristen yang terdapat pada Kejadian 2:24 bahwa: "laki-laki akan meninggalkan ayah dan ibunya dan bersatu dengan isterinya dan keduanya menjadi satu daging," memiliki makna pernikahan yang penting yaitu pernikahan sebagai suatu persekutuan yang hidup. Persekutuan yang hidup itu terjadi secara terus-menerus, hanya pada satu pasangan, memiliki kesepahaman terhadap prinsip-prinsip mendasar dan terutama berdasarkan kasih: di dalam kasih kepada Allah dan kasih antara suami-isteri sehingga menjadi satu tubuh baik jasmani (seksual) maupun rohani. ${ }^{41}$ Bagi Kekristenan, pernikahan adalah sesuatu yang sakral dan dilakukan sekali seumur hidup. Sehingga, suatu pernikahan itu harus dilakukan berdasarkan kasih, bukan karena paksaan karena tekanan budaya-budaya tertentu. Apalagi, tidak memiliki kesesuaian-kesesuaian prinsipil tertentu akibat proses perkenalan yang tidak dijalankan dengan baik. Sehingga, tidak jarang menimbulkan banyak sekali masalah dalam rumah tangga seperti ketidakharmonisan dalam keluarga, kekerasan dan perselingkuhan.

Kemudian, menurut ajaran Kristiani, anak-anak adalah anugerah dari Allah menjadi mahkota berkat bagi orang tua (Amsal 17:6). Seperti kisah-kisah tokoh dan nabi-nabi besar yang mandul tetapi diberikan anak dengan mukjizat dari Allah. Di antaranya kisah Abraham dan Sarah diberikan anugerah yakni anaknya Ishak sebagai simbol perjanjian Allah dengan Abraham dan melalui itu Abraham serta bangsanya mendapat berkat: banyaknya keturunan mereka seperti pasir dan bintang di langit. Begitupun juga kisah Rahel, Hana dan keluarga lainnya dalam Alkitab yang dikaruniai anak dari Tuhan sehingga membawa berkat bagi mereka.

Yesus Kristus sendiri pun sangat peduli dan mengasihi anak-anak, bahkan kita diajar untuk meneladani sikap-sikap murni anak-anak agar berkenan memenuhi kriteria kerajaan Allah (Markus 10:13-16). Sebaliknya, tidak boleh mengeksploitasi anak oleh sebab-sebab tertentu seperti kemiskinan dan lain-lain karena itu merupakan kekejian bagi Tuhan. Dari uraian di atas dapat disimpulkan bahwa dalam nilai-nilai Kekristenan anak merupakan anugerah yang sangat berharga untuk dilindungi dan diperlakukan dengan baik sesuai dengan hak-hak mereka. 
Dalam hal ini, anak yang telah di berikan sebagai maskawin, harus harus tetap diperlakukan dengan penuh kasih sayang dan bertanggung jawab kepada Allah dalam merawat, mendidik anak tersebut. Menurut hemat penulis, akan lebih baik jika, anak bisa bersama-sama dengan orang tua kandungnya, karena itu merupakan hak anak dan orang tua biologis yang lebih memiliki hubungan emosional. Selain itu, agar tidak mengalami kebingungan mengenai asal-usul biologisnya. Walaupun, pada realitanya para orang tua asuh memberikan kasih sayang dan perawatan yang sama seperti anak kandungnya sendiri hal itu dilakukan oleh masyarakat Isirawa.

Oleh karena itu, gereja pun perlu peka, kritis, bertindak memberi pemahaman kepada umat mengenai permasalahan ini, dan dapat berteologi sesuai konteks suku Isirawa. Ini bukanlah proses yang singkat karena berkaitan dengan budaya yang sudah ada sejak dahulu. Mengingat Budaya maskawin dalam pernikahan tukar ini sangat berarti bagi masyarakat Isirawa maka, penulis tidak bermaksud menghakimi budaya tersebut. Kita bukan hakim yang menyatakan budaya tertentu sebagai sesuatu yang baik atau buruk tanpa melihat dari sudut pandang pemilik budaya tersebut. Tentunya setiap budaya perlu dihormati karena itu merupakan jati diri bangsa. Oleh karena itu, yang dapat kita lakukan adalah memberi solusi, pemahaman dan makna atau nilai Kristiani baru terhadap budaya maskawin dalam pernikahan tukar tersebut dan mengubah tradisi yang memarjinalkan. Agar tata aturan tradisi yang ada dapat menyejahterakan tanpa ada yang dirugikan atau menderita.

\section{KESIMPULAN}

Maskawin dalam pernikahan tukar-menukar perempuan dan anak adalah sesuatu budaya yang unik dari Masyarakat Isirawa dan sebenarnya memiliki makna yang positif bahwa perempuan dan anak adalah pribadi yang sangat berharga dan memiliki peran penting bagi masyarakat Isirawa untuk mempererat kekerabatan, sebagai alat pembayaran untuk menciptakan perdamaian dalam konflik, meneruskan marga dan diharapkan sebagai pencegah kekerasan yang terkandung dalam nilai aturan maskawin tersebut. Tetapi, di lain sisi ternyata menimbulkan dampak negatif yang disadari atau tidak telah memarjinalkan atau menimbulkan perlakuan tidak adil terhadap perempuan dan anak yaitu mereka tidak memiliki kebebasan untuk memilih atau berkuasa atas dirinya sendiri, dan akhirnya menimbulkan beberapa bentuk 
kekerasan berupa tekanan atau paksaan terhadap perempuan. Selain itu, berakibat pada maraknya pernikahan tidak sah dan banyaknya kasus ketidakharmonisan dalam rumah tangga akibat tidak terjadinya proses perkenalan dan penyesuaian dasar-dasar prinsipil kedua calon pasangan sebelum pernikahan karena sistem pernikahan tukar tersebut.

Sehingga, jika dilihat dari sudut pandang feminis beberapa hal tersebut sangat tegas untuk dikritik karena menjadikan perempuan dan anak "seperti" properti yang lebih banyak merugikan kaum perempuan. Walaupun terkadang, sebagian masyarakat Isirawa secara khusus para perempuan tidak begitu menyadari ketertindasan atau menerima saja budaya tersebut karena tata aturan adat yang sudah mengikat dan berlaku secara turun-temurun. Di ain sisi, karena budaya maskawin dalam pernikahan tukar ini adalah identitas bagi masyarakat Isirawa maka, perlu dipertimbangkan untuk tidak serta-merta menghakimi budaya tersebut begitu saja. Tetapi, sebaiknya perlu dipertimbangkan untuk mengubah beberapa tradisi yang memarjinalkan dengan memberi solusi, pemahaman dan nilai Kristiani yang baru oleh gereja dengan melibatkan seluruh unsur masyarakat adat dan pemerintah yang ada, agar tetap melestarikan budaya sekaligus tidak bertentangan dengan ajaran Kristen dan hukum kemanusiaan. Karena ada beberapa faktor yang melatarbelakangi pertukaran manusia tersebut, salah satunya adalah faktor ekonomi yang mungkin harus lebih diperhatikan oleh pemerintah dan gereja.

\section{Endnotes:}

\footnotetext{
${ }^{1}$ Hildred Geertz, Aneka Budaya Dan Komunitas Di Indonesia, 1st ed. (Yayasan Ilmu-ilmu Sosial, FISUI, 1981): 1 .

${ }^{2}$ Ryan Prayogi and Endang Danial, "Pergeseran Nilai-Nilai Budaya Pada Suku Bonai Sebagai Civic Culture Di Kecamatan Bonai Darussalam Kabupaten Rokan Hulu Provinsi Riau," Humanika 23, no. 1 (2016): 64.

${ }^{3}$ Erni Hastuti and Teddy Oswari, "Budaya Pernikahan Masyarakat Minang Rantau Di Jakarta," UG Jurnal 10, no. 8 (2016): 1-11.

${ }^{4}$ Shulamit Reinharz, Feminist Methods in Social Research -Oxford University Press, USA (1992) (New York: Oxford University Press, 1992), 51.

${ }^{5}$ Koentjaraningrat et al., Kamus Istilah Antropologi (Jakarta: Departemen Pendidikan dan Kebudayaan, 1984), 143.

${ }^{6}$ J.L.Ch. Abineno, Sekitar Etika Dan Soal-Soal Etis (Jakarta: BPK. Gunung Mulia, 2010), 56-73.
} 
${ }^{7}$ Koentjaraningrat et al., Kamus Istilah Antropologi, 111.

${ }^{8}$ Koentjaraningrat et al., 3 \& 145.

9 Pemerintah Kabupaten Sarmi, "Website Selayang Pandang Kabupaten Sarmi,” 2018, https://www.sarmikab.go.id/.

${ }^{10}$ Koentjaraningrat and Bactiar Harsja W, Penduduk Irian Barat (Jakarta: P.T. Penerbitan Universitas (UI), 1963), 159.

${ }^{11}$ Sarmi, "Website Selayang Pandang Kabupaten Sarmi."

${ }^{12}$ GKI Talitakum Wari, Hasil Sidang Jemaat GKI Talitakum Wari Ke-III (Kampung Wari, 2018).

${ }^{13}$ Koentjaraningrat and Harsja W, Penduduk Irian Barat, 161.

${ }^{14}$ Marinus Sunuk, "Hasil Wawancara Guru Injil oleh Penulis" (2018).

${ }^{15}$ Koentjaraningrat and Harsja W, Penduduk Irian Barat, 165.

${ }^{16}$ Koentjaraningrat and Harsja W, 165.

${ }^{17}$ Koentjaraningrat and Harsja W, 167-69.

${ }^{18}$ Koentjaraningrat and Harsja W, 170.

${ }^{19}$ Yohan Sunuk, "Hasil Wawancara Kepala Adat Kampung Wari oleh Penulis" (2018).

${ }^{20}$ Sunuk, "Hasil Wawancara Guru Injil Oleh Penulis."

${ }^{21}$ Maya Kasim, "Dampak Mas Kawin Kakena Bagi Kehidupan Perempuan Di Kampung Karfasia Apawer Hilir Sarmi” (Skripsi S.Th., STFT GKI I.S. Kijne, 2020), 37-38.

${ }^{22}$ Sunuk, "Hasil Wawancara Guru Injil Oleh Penulis."

${ }^{23}$ Sunuk.

${ }^{24}$ Sunuk.

${ }^{25}$ Sunuk.

${ }^{26}$ Koentjaraningrat and Harsja W, Penduduk Irian Barat, 171.

${ }^{27}$ Hagar Sunuk, "Hasil Wawancara Warga Oleh Penulis" (2020).

${ }^{28}$ Kiririt Oskar, "Hasil Wawancara Warga Oleh Penulis" (2020).

${ }^{29}$ Veni Sunuk, "Hasil Wawancara Warga Oleh Penulis" (2020).

${ }^{30}$ Sunuk, "Hasil Wawancara Guru Injil Oleh Penulis."

${ }^{31}$ Sunuk.

${ }^{32}$ Sunuk, "Hasil Wawancara Warga Oleh Penulis," 2020.

${ }^{33}$ Mansour Fakh, Analisis Gender Dan Transformasi Sosial (Yogyakarta: Pustaka Pelajar, 1999), $12,147 \& 151$.

${ }^{34}$ Basilica Dyah Putranti dan Asnath Niwa Nata, Perempuan, Konflik, Dan Rekonsiliasi: Perspektif Teologi Dan Praksis (Jakarta: BPK. Gunung Mulia, 2016), 2, 3, dan 6.

${ }^{35}$ Eka Kristining Rahayu, "Tinjauan Teologis Terhadap Budaya Patriarkal Di Indonesia," Pengarah: Jurnal Teologi Kristen 1, no. 2 (2019): 114 \& 118.

${ }^{36}$ Ruth Schafer et al., Menggugat Kodrat Mengangkat Harkat, ed. Rika Uli Napitupulu, 1st ed. (Jakarta: BPK. Gunung Mulia, 2014), 2 \& 4.

${ }^{37}$ Schafer et al., $2 \& 4$.

${ }^{38}$ Schafer et al., 1.

${ }^{39}$ Rahayu, "Tinjauan Teologis Terhadap Budaya Patriarkal Di Indonesia," 118-119.

${ }^{40}$ Schafer et al., Menggugat Kodrat Mengangkat Harkat, 7.

${ }^{41}$ Abineno, Sekitar Etika Dan Soal-Soal Etis, 66 \& 73. 


\section{DAFTAR PUSTAKA}

Abineno, J.L.Ch. Sekitar Etika Dan Soal-Soal Etis. Jakarta: BPK. Gunung Mulia, 2010.

Fakh, Mansour. Analisis Gender Dan Transformasi Sosial. Yogyakarta: Pustaka Pelajar, 1999.

Geertz, Hildred. Aneka Budaya Dan Komunitas Di Indonesia. 1st ed. Yayasan Ilmuilmu Sosial, FIS-UI, 1981.

Hastuti, Erni, and Teddy Oswari. "Budaya Pernikahan Masyarakat Minang Rantau Di Jakarta.” UG Jurnal 10, no. 8 (2016): 1-11.

Kasim, Maya. "Dampak Mas Kawin Kakena Bagi Kehidupan Perempuan Di Kampung Karfasia Apawer Hilir Sarmi.” Skripsi S.Th., STFT GKI I.S. Kijne, 2020.

Koentjaraningrat, Arini Sofion Budhisantoso, J. Danandjaya, and E.K.M. Masinambow. Kamus Istilah Antropologi. Jakarta: Departemen Pendidikan dan Kebudayaan, 1984.

Koentjaraningrat, and Bactiar Harsja W. Penduduk Irian Barat. Jakarta: P.T. Penerbitan Universitas (UI), 1963.

Nata, Basilica Dyah Putranti dan Asnath Niwa. Perempuan, Konflik, Dan Rekonsiliasi: Perspektif Teologi Dan Praksis. Jakarta: BPK. Gunung Mulia, 2016.

Oskar, Kiririt. "Hasil Wawancara Warga Oleh Penulis.” 2020.

Prayogi, Ryan, and Endang Danial. "Pergeseran Nilai-Nilai Budaya Pada Suku Bonai

Sebagai Civic Culture Di Kecamatan Bonai Darussalam Kabupaten Rokan Hulu Provinsi Riau." Humanika 23, no. 1 (2016).

Rahayu, Eka Kristining. "Tinjauan Teologis Terhadap Budaya Patriarkal Di Indonesia." Pengarah: Jurnal Teologi Kristen 1, no. 2 (2019).

Reinharz, Shulamit. Feminist Methods in Social Research -Oxford University Press, USA (1992). New York: Oxford University Press, 1992.

Sarmi, Pemerintah Kabupaten. "Website Selayang Pandang Kabupaten Sarmi," 2018. https://www.sarmikab.go.id/.

Schafer, Ruth, Frisca Imelda, Ina Melyana, Dara Natalia Kristina, and Muliathy 
Briany. Menggugat Kodrat Mengangkat Harkat. Edited by Rika Uli Napitupulu. 1st ed. Jakarta: BPK. Gunung Mulia, 2014.

Sunuk, Hagar. "Hasil Wawancara Warga Oleh Penulis.” 2020.

Sunuk, Marinus. "Hasil Wawancara Guru Injil Oleh Penulis.” 2018.

Sunuk, Veni. "Hasil Wawancara Warga Oleh Penulis.” 2020.

Sunuk, Yohan. "Hasil Wawancara Kepala Adat Kampung Wari Oleh Penulis.” 2018.

Wari, GKI Talitakum. Hasil Sidang Jemaat GKI Talitakum Wari Ke-III. Kampung Wari, 2018. 